[Vicino Oriente XVII (2013), pp. 7-20]

\title{
ESTAKHR PROJECT - SECOND PRELIMINARY REPORT OF THE JOINT MISSION OF THE IRANIAN CENTER FOR ARCHAEOLOGICAL RESEARCH, THE PARSA-PASARGADAE RESEARCH FOUNDATION AND THE SAPIENZA UNIVERSITY OF ROME, ITALY
}

\author{
Nasser Noruz Zadeh Chegini - Iranian Centre for Archaeological Research - \\ Maria Vittoria Fontana - Sapienza University of Rome - \\ Ali Asadi - Parsa-Pasargadae Research Foundation - \\ Martina Rugiadi - Alessandro Maria Jaia - Alessandro Blanco - Laura Ebanista - \\ Sapienza University of Rome - \\ Valentina Cipollari - Independent Scholar
}

\begin{abstract}
La trincea aperta nel corso di questa prima campagna di scavo, a ovest della moschea, ha evidenziato almeno otto fasi. La fase 1 è relativa al muro esterno della moschea, dotato di un'apertura e di una torre semicircolare. Di particolare interesse (fase 2) è un asse stradale lastricato, connesso a una rilevante dorsale fognaria. L'articolazione della strada, già messa in evidenza dalle indagini geofisiche, sembra delimitare un importante quartiere a ovest della moschea. L'asse stradale, pur subendo un parziale rifacimento sul lato ovest (fase 3), conserva la sua fisionomia fino a tutta la fase 4. La successiva sovrapposizione di più livelli stradali in terra battuta che obliterano la strada lastricata, restringendone la carreggiata pur conservandone l'orientamento (fase 5), sembra mettere in evidenza la perdita di rilevanza del quartiere ad ovest della moschea, probabilmente in corrispondenza di una fase di decadenza della compagine urbana risalente all'XI secolo.
\end{abstract}

Keywords: Estakhr; Iran; Early Islamic; Sasanian; archaeology

The second season of archaeological activities of the joint Iranian-Italian Archaeological Mission in Estakhr was carried out from October $12^{\text {th }}$ to November $9^{\text {th }}$, 2012 under the joint direction of Nasser Noruz Zadeh Chegini (Iranian pre-Islamic Archaeology, formerly Director of the Iranian Centre for Archaeological Research) and Maria Vittoria Fontana (Islamic Archaeology, Sapienza University). ${ }^{1}$ Participating institutions included the Iranian Centre for Archaeological Research (ICAR), the ParsaPasargadae Research Foundation (PPRF) and the Sapienza University of Rome (Sapienza). The research team was composed of Martina Rugiadi, field director, archaeologist (Sapienza), Ali Asadi, field director, archaeologist (PPRF), Alessandro M. Jaia, topographer and archaeologist (Sapienza), Alessandro Blanco, topographer and archaeologist (Sapienza), Valentina Cipollari, topographer and archaeologist, Laura

The second campaign was funded by the Sapienza University of Rome, the Fondation Max van Berchem of Geneva and the Italian Ministry of Foreign Affairs. 
Ebanista, topographer and archaeologist (Sapienza), Ali Moludi (MA student) and Malihe Tahmasbi (draftsman). Thirteen university students joined the research team.

The main aim of the season was to investigate the area west of the mosque ${ }^{3}$ in order to verify the presence of a monumental building identified by D. Whitcomb on one of E.F. Schmidt's aerial photographs. Whitcomb suggested that this structure could be the $7^{\text {th }}$ century dar al-imara (governmental palace), built when Estakhr was capital of the Fars province. The combination of mosque and dar al-imara is known from other Islamic cities, but no examples have been found yet in the Iranian region. In the course of the first season (May 2012), a 3D digital terrain model (DTM) was made of the same area shown in the aerial photograph (see below). ${ }^{5}$ The results seemed to contradict those implied by the aerial photograph, however, since a deep depression appears in the area corresponding to the line of the wall of the suggested building, while patches of elevated ground appeared to the west of that line, almost parallel to it. The geophysical survey and the excavation undertaken during the second season helped explaining the question.

\section{GEOPHYSICAL SURVEY}

The geophysical survey was carried out in three squares in the area west and northwest of the remains of the mosque. The investigation was conducted by Sébastien Gondet (Bologna University) and Kourosh Mohammadkhani (Lyon 2 University) by gracious permission of the Persepolis Project directed by P. Callieri and A.R. Askari.

The squares $(50 \times 50 \mathrm{~m}$ each) cover the area in Schmidt's aerial photograph that Whitcomb identified as the northern part of the palace. The results show a strong anomaly, square in shape (fig. 1), having approximately the same orientation of the mosque and following almost precisely the route of the lines visible in the aerial photograph.

The corresponding depression of the ground shown in the digital terrain modeling called its nature into question.

Mohsen Armat, Mohammad Derakhshah, Mohsen Emadi, Vahed Fatehi, Reza Golbakhsh, Fazollah Habibi, Hamid Reza Kahami Dekhsheykhi, Jawad Keshavarzi, Ahmad Monozahian, Hamid Mowlayi, Abuzar Tavakkol, Salar Vatandust, Hamid Reza Zare.

Estakhr, about $60 \mathrm{~km}$ north of Shiraz, and about $5 \mathrm{~km}$ north of Persepolis, is enclosed by walls; few remains of a large mosque are preserved.

Schmidt 1940, pl. 10; Whitcomb 1979, 366, ill. at p. 367.

The first season was mainly devoted to a first general survey of the town and a detailed topographic survey (Fontana et al. 2012).

A short survey was also carried out in the area northeast of the city wall in order to plan future geophysical investigations. The ground is characterized by being largely covered by pottery fragments, to such an extent which led to speculate the presence of a dump and/or of a manufacturing quarter. This is also substantiated by the enormous amount of metal and of pottery slags, as well as of pottery molds and other finds probably related to production activities. For these reasons, the area will be avoided in future geophysical investigations. 


\section{EXCAVATION}

An excavation trench was set out in the same area in order to encompass not only the lines detected in the aerial photograph and the anomaly of the geophysical survey, but also the patches of elevated ground to their west. The selected area starts from the opening in the mosque wall first detected during the $1^{\text {st }}$ season, a feature that could be significant for the connection of the mosque with the supposed building. The excavated trench is oriented east-west and is orthogonal to the opening of the mosque wall. It measures $20.90 \times 2 \mathrm{~m}$ and is up to 4.49 - $4.90 \mathrm{~m}$ wide in the area close to the mosque (pl. I:A).

Excavations revealed a paved street and sewer that corresponded to the anomaly of the geophysical survey (surely in use in Phases 2-4). If confirmed, this conclusion might prove to be very useful for the continuation of geophysical investigations on the site in the future. The street uncovered in the east part of the trench and the walls retrieved in the west part of it also conform to the forms shown in the digital terrain modeling.

In the trench, at least eight phases were identified.

Phase 1 (light blue in pl. I:A) relates to the exterior part of the mosque wall (fig. 2). This is a wall of substantial thickness (1.82 to $1.95 \mathrm{~m}$ ) made of local limestone chips of various sizes, joined with a small amount of mortar (WSU 1).

The relatively modest opening ( 0.91 - $0.9 \mathrm{~m}$ wide) proved to be a door. Its jambs are detached from the wall and made of corner-stones bound with very friable yellow mortar, larger than the stones of the mosque. The joining elements between door jambs and face bricks seem to exclude the possibility that the door was opened after the construction of the mosque wall: the building technique and materials are the same, and there are no traces of filling of the wall on the exterior.

A semi-circular tower was brought to light on the same wall, just south of the door (WSU 2: diameter $1.85 \mathrm{~m}$ including the exterior of the wall, variable thickness 0.28 to 0.58 $\mathrm{m})$. The wall is made up of fragments of limestone bound with very firm white mortar, found more abundantly between stones close to the façade (west side). It contains a filling of loose material. The tower was clearly not planned as part of a monumental entryway, as there is no evidence of a second tower on the northern side of the door. E. Flandin and P. Coste, who travelled during the years 1840 and 1841, reproduced a plan of the mosque (interpreted as a "palais") with five semi-circular towers along the west side and two threequarters round towers on the corners of the same side.

The excavation stopped at the level of the door threshold. In the next season we intend to investigate the area immediately west of the door, that may provide elements of chronological significance. At present, it is advisable to consider the mosque as the oldest element of the excavated area, isolating it in Phase 1.

The results of the excavation of Phase 1 show that when the mosque was built a small secondary door was planned on its qibli wall, to allow access between the mosque and the area encompassed by our investigations.

In Phase 2 (light ochre in pl. I:A), a stretch of a large paved street was uncovered (WSU 131, fig. 3) that had collapsed along its eastern side. The street was more than $6 \mathrm{~m}$ wide,

Flandin - Coste 1851, pl. 58, below; see also p. 70. 
and covered a sewer (WSU 182). It is paved with square slabs of local hard stone, arranged radially, with traces of wear. There are no cart tracks. The paving is altered or absent in the western sector, which was mostly rebuilt using flakes of stones from the original paving (Phase 3).

The sewer ( $0.40 \mathrm{~m}$ wide; $0.50 \mathrm{~m}$ deep) runs below the east side of the street, sloping towards the south. Its vertical sides are made of bricks coated with hydraulic mortar (fig. 4). The sewer was covered with limestone blocks, partly preserved on the southern side. Further excavations might show the chronological connection between the mosque and the street, and possibly allow for them to be considered part of the same phase. The pottery found in the filling of the sewer (SU 183-184) is not well known enough to use in establishing a date for its closure. One fragment of splash-ware found can be broadly attributed to the $9^{\text {th }}-11^{\text {th }}$ century.

Phase 2a (ochre in pl. I:A) relates to two elements, both located west of the street and at the same level as phase 2 .

The first is a compact and well-smoothed floor level found immediately to the west of the street (SU 176). Inserted in the floor is part of a tannur (SU 188, fig. 5), which appears to be cut by a later construction, probably not earlier than the $11^{\text {th }}$ century (see Phase 3). A number of pottery sherds found in the layer that covers the tannur and the floor suggest an $11^{\text {th }}$ century date (SU 160). These included one fragment of graffita $\left(10^{\text {th }}\right.$ century $-11^{\text {th }}$ century), fragments of unglazed molded wares (similar to closed vessels produced in various centers in Iran and Central Asia, attributed to the $11^{\text {th }}-12^{\text {th }}$ century), ${ }^{9}$ and of unglazed wares with emerging inclusions (including vegetal chaff) on their surfaces. The fabric of the latter suggests that they might be related to the unglazed painted wares appearing in Phase 4 and which are attributed to a range of dates from the $11^{\text {th }}$ century or slightly earlier to the $14^{\text {th }}$ in the scholarly literature. This date range is to be verified for Estakhr.

The second element designated Phase 2a is represented by the northeast corner of a room located at the western end of the trench (WSU 155 and 196), oriented in the same direction as the mosque. The preparation layer for its floor (SU 168 and 169) is preserved (fig. 6).The fragments that were retrieved in this layer include one fragment of imported Iraqi monochrome gold lustre ware (white opaque glaze on a cream-yellow, medium soft and compact fabric, dated to the end of the $9^{\text {th }}-10^{\text {th }}$ century). ${ }^{11}$ The layers that cover the preparation layer (SU 161, 158) contained a fragment of opaque glazed ware with turquoise-green splashes related to the wares of the so-called "Samarra horizon" $\left(9^{\text {th }}-10^{\text {th }}\right.$

As the raw data will take some time to process, the information given in this report are mostly limited to the chronological value of the excavated pottery. It has to be noted that in the present state of knowledge about Sasanian and Islamic pottery in Fars, especially with the lack of stratigraphic data, comparisons are unlikely to give a reliable chronological assessment. The chronology given in this report is thus intentionally very broad. SU 183-184 included 25 pottery fragments: unglazed with fine, medium and coarser fabrics (15), 1 with comb-incisions; 5 fragments of monochrome green glazed ware, 1 fragment of splashed ware. Siméon 2009, 54-57, lists comparative materials.

10 Also called pseudo-prehistoric and Madabad wares (Sumner - Whitcomb 1999, 320-321, with previous bibliography).

11 Northedge 2001, 211-212. 
century), ${ }^{12}$ and a glazed fragment probably related to graffita wares. These fragments give a terminus post quem in the $10^{\text {th }}$ century for this layer.

The walls of this room ( $0.80 \mathrm{~m}$ wide) are composed of roughly chopped slabs of local hard stone bound with mortar. The inner side of the wall shows the scarcement of its foundation.

Fragments of red painted coarse mortar were found in the layer that covers the floor preparation layer (SU 158).

Phase 3 (green in pl. I:A) is the result of a complete makeover of the area that overlooks the west side of the street. It includes the northeast corner of a room (WSU 115 north-south wall, WSU 197 east-west wall). The walls, oriented slightly differently than those of the mosque, were built ex novo from the foundations and cut the tannur of Phase 2a. The floor of the room is at the same level as the street.

A slab from the street was re-employed at the top of the wall WSU 115. At this time, the street appears to have been partially dismantled and then repaved with stones and slabs arranged differently than before. The connection between the new construction and the street paving suggests the persistence of the use of the street at this stage.

The new structure (WSU 115) is realized ex novo, without using previous structures for its foundation (at least not on the side of the street). It is thus possible that in the previous period, in Phase 2-2a, this area between the street and the Phase 2a building (of which the northeast corner only was excavated, WSU 155 and 196) was free or that a fence/wall only separated them. The latter could have been located in the west side of the street that appears mended with road metal and re-employed slabs from the original paving.

Phase 4 (pink in pl. I:A) represents the abandonment of the street. The likely decline of this area is evidenced by the closing down of a tannur located at the door of the mosque (SU 185), whose hob is set at the same level of the street and of the mosque door (fig. 7). Fragments of the clay walls of the tannur collapsed inside it. The layer that fills the tannur (SU 179) contained the earliest fragments of unglazed painted wares found in the trench and fragments of unglazed molded wares - giving a terminus post quem in the $11^{\text {th }}$ century. Another tannur was identified in the south east corner of the enlargement of the trench, close to the tower.

During Phase 5 a sequence of levels that had slipped from the east part of the trench towards the west attests to the collapse of the western wall of the mosque (SU 119, 141, 146 and 135; pl. I:B) and the abandonment of the area. In this phase, the street is covered by layers corresponding to a narrower path on the west (SU 163, 152 and 159; pl. I:B).

From the collapse of the western wall of the mosque (SU 119, 141, 146 and 135) a large number of unglazed fragments probably related to molded wares came to light, while fewer unglazed painted fragments were found. The glazed wares found in the same layer are to be attributed up to the $10^{\text {th }}$ or early $11^{\text {th }}$ century: splashed (fig. 10:A), graffita, monochrome green (fig. 10:B), opaque turquoise glazed (fig. 10:D). From SU 141 a fragment of a capital in grey stone (fig. 8) was also brought to light. It might have been originally part of a bellshaped capital of the Achaemenid period; Chegini suggests that it might have been re-

Priestmann 2011, 104-107 with previous references. 
employed in the Sasanian period. At any rate, it was re-employed for the building of the mosque as attested by the mortar placed on the fracture.

The ceramics retrieved from the layers of the path that effaced the street include molded earthenware fragments $\left(11^{\text {th }}-12^{\text {th }}\right.$ centuries) and a fragment of an opaque turquoise-glazed earthenware basin (fig. 10:C), with a bird-like applied decoration. A similar ware was found in the late $11^{\text {th }}$ century layers of the masjed-e jom ' $e$ in Esfahan. ${ }^{13}$

Phase 6 (grey in pl. I:A) is represented by a wall oriented east-west in the western side of the trench (WSU 147). The wall is composed of reused bricks and irregular limestone blocks, set without mortar. This structure rests on a layer of earth and covers the walls below (Phase 3).

Phase 7 consists of a pottery dump (SU 142, fig. 9) located approximately in the middle of the trench. The recovered pottery, which consisted of several unglazed vessels that were nearly complete, can be assigned to a period between the $10^{\text {th }}$ and $14^{\text {th }}$ centuries (fig. 11:AD).

Phase 8 shows recent agricultural activity (traces of plough SU -103, -104, -105, -106, 107, -108, -109), immediately below the humus layer (SU 101) as well as animal farming (layer of ashes surrounded by stones and bricks SU 116). The pottery assemblage recovered from these layers does not differ significantly from those found in layers related to earlier phases, except for the proportions. Unglazed painted ware is more frequent than in the lower layers.

\section{CONCLUSIONS}

Within the sequence of phases brought to light in the excavation, the paved street and its sewer are particularly relevant. Their orientation and development, also detected by the geophysical survey, seem to define a chief quarter that was situated to the west of the mosque. The street, while undergoing a partial reconstruction on its west side (Phase 3) was maintained throughout the entire period represented by Phase 4 .

Later, several layers of dirt road covered the paved street (Phase 5). These paths conformed to the orientation of the street, but their width is reduced in respect to the street. These developments point to a decline in the relevance of the quarter to the west of the mosque, most probably connected with the decay of Estakhr's main urban structure in the $11^{\text {th }}$ century.

Rugiadi 2011, 234. 
This project is sponsored by the Max van Berchem Foundation, established in 1973 in memory of Max van Berchem (1863-1921), the founder of Arabic epigraphy. Based in Geneva, the aim of the Foundation is to promote the study of Islamic and Arabic archaeology, history, geography, art, epigraphy, religion and literature.

\section{REFERENCES}

FLANDin, E. - Coste, P.

1851 Voyage en Perse de M.M. Eugène Flandin, peintre, et Pascal Coste, architecte, attachés à l'ambassade de France en Perse, pendant les années 1840 et 1841, Paris 1851.

Fontana, M.V. - Mireskandari, S.M. - Rugiadi, M. - Asadi, A. -Jaia, A.M. - Blanco, A. Colliva, L.

2012 Estakhr Project - first preliminary report of the joint Mission of the Iranian Center for Archaeological Research, the Parsa-Pasargadae Research Foundation and the Sapienza University of Rome, Italy: Vicino Oriente XVI (2012), pp. 167-180.

NORTHEDGE, A.

2001 Thoughts on the Introduction on Polychrome Glazed Pottery in the Middle East: E. VILLENEUVE - P.M. WATSON (eds.), La céramique byzantine et proto-islamique en SyrieJordanie (IVe-VIIIe siècles apr. J.-C.). Actes du colloque tenu à Amman les 3, 4 et 5 décembre 1994, Beyrouth 2001, pp. 207-214.

PRIESTMAnN, S.

2011 Opaque Glazed Wares: a Review of the Definition, Dating and Distribution of a Key Iraqi Ceramic Export in the Abbasid Period: Iran 49 (2011), pp. 89-114.

RUGIADI, M.

2011 The Emergence of Siliceous-Paste in Iran in the Last Quarter of the $11^{\text {th }}$ century and Related Issues. The Dated Assemblage from the Southern Domed Hall of the Great SCHMIDT, E.F. Mosque of Isfahan: Vicino \& Medio Oriente XV (2011), pp. 233-248.

$1940 \quad$ Flights over Ancient Cities of Iran, Chicago 1940.

SIMEON, M.P.

2009 Étude du matériel de Hulbuk (Mā warā'al-nahr-Khuttal), de la conquête islamique jusqu'au milieu du XI siècle (90/712-441/1050): contribution à l'étude de la céramique islamique d'Asie centrale (British Archaeological Reports. International Series 1945), Oxford 2009.

SuMNER, W. - WHITCOMB, D.

1999 Islamic Settlement and Chronology in Pars: an Archaeological Perspective: Iranica Antiqua XXXIV (1999), pp. 309-323.

WHITCOMB, D

1979 The City of Istakhr and the Marvdasht Plain: D. REIMER (ed.), Akten des VII. Internationalen Kongress für Iranische Kunst und Archäologie, München 7.-10. September 1976 (Archaeologische Mitteilungen aus Iran: Ergänzungsband 6), Berlin 1979, pp. 363-370. 


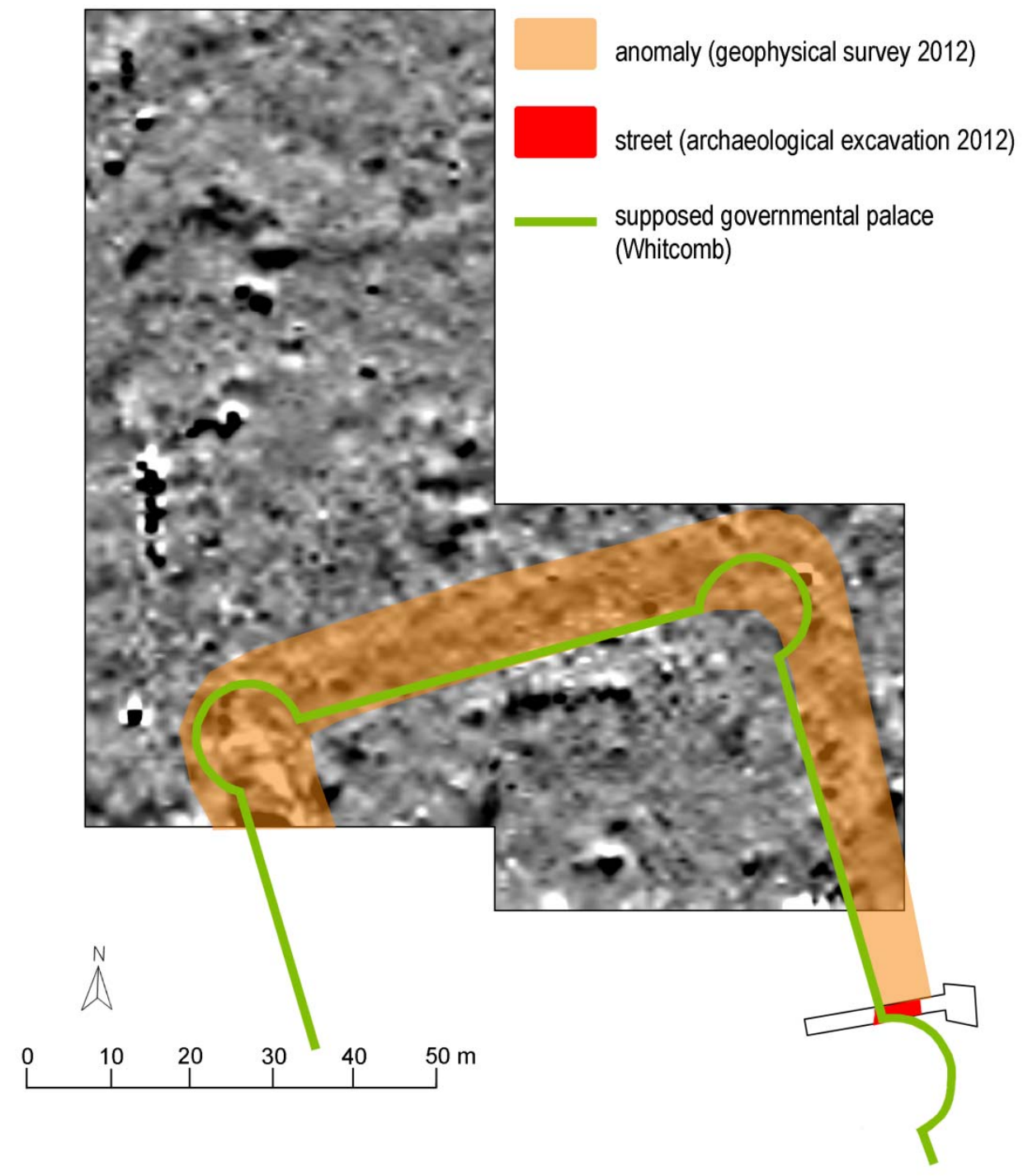

Fig. 1 - Estakhr - The anomaly in the geophysical survey (outlined in green is the palace as hypothesized by D. Whitcomb 1979; rendering L. Ebanista). 


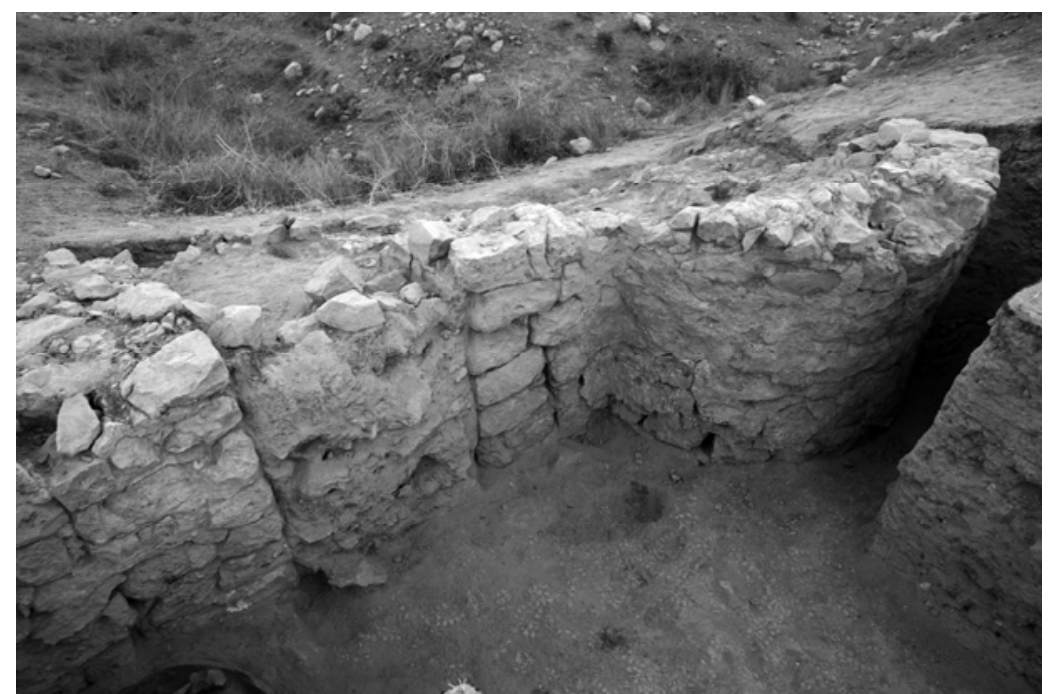

Fig. 2 - Estakhr - Phase 1 - The wall of the mosque showing the door and the semi-circular tower (photo A.M. Jaia).

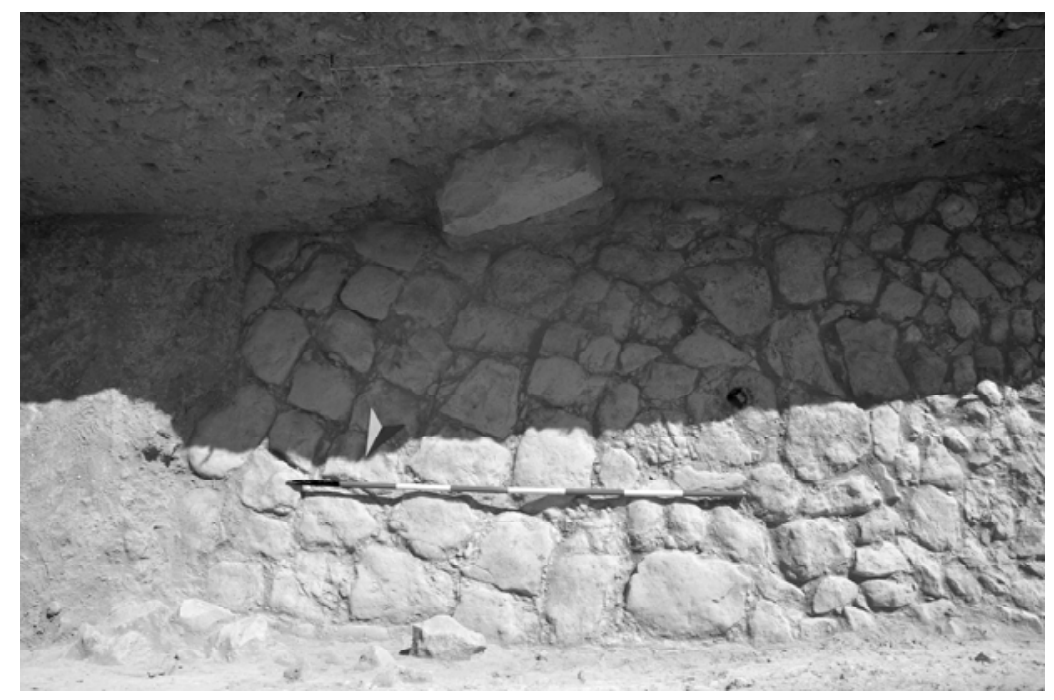

Fig. 3 - Estakhr - Phase 2 - The paved street (view from North; photo L. Ebanista). 


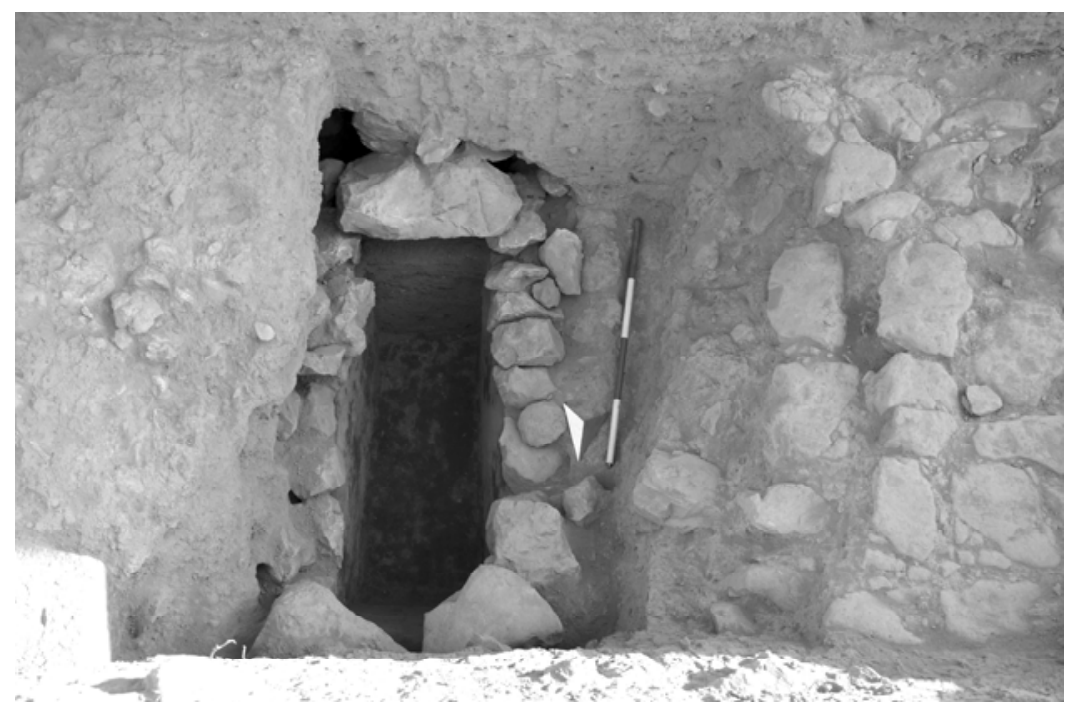

Fig. 4 - Estakhr - Phase 2 - The sewer under the paved street (photo L. Ebanista).

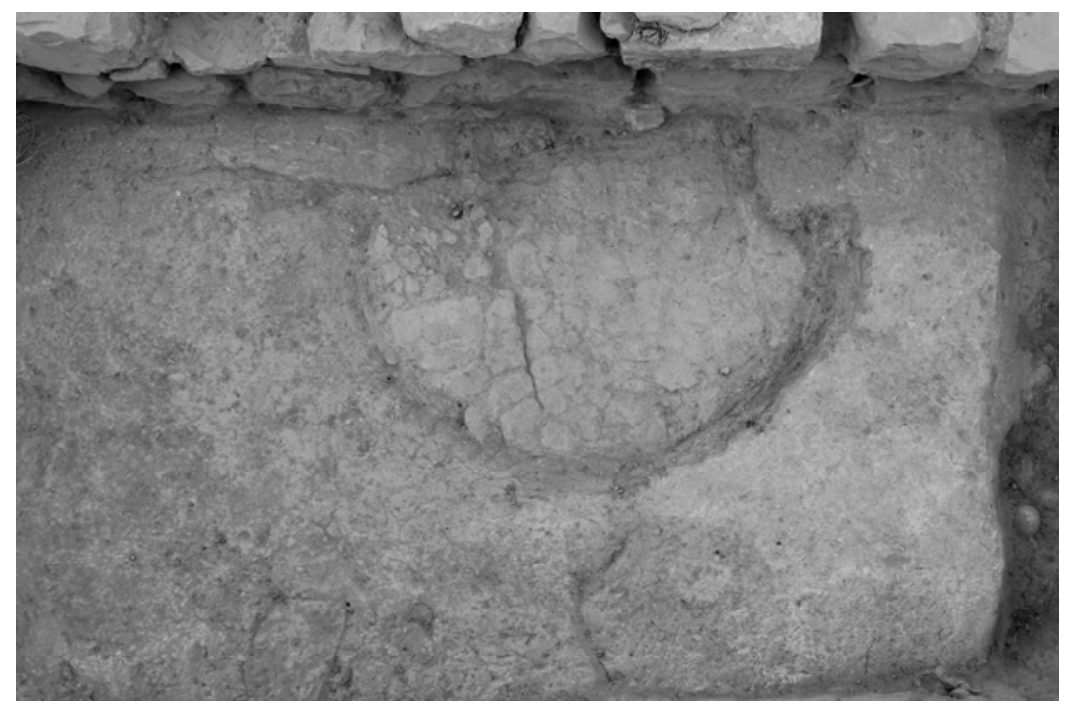

Fig. 5 - Estakhr - Phases 2a and 3 - The tannur cut by the foundation of the walls WSU 197 (photo A. Blanco). 


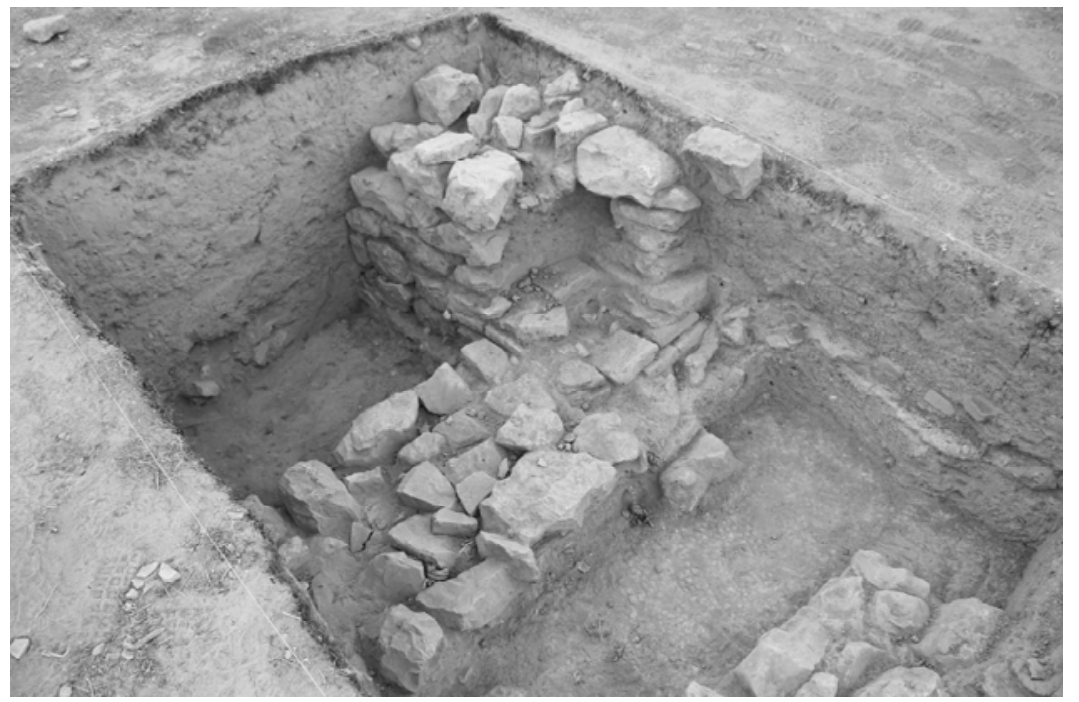

Fig. 6 - Estakhr - Phase 2a - Room set in the west side of the trench (photo A. Blanco).

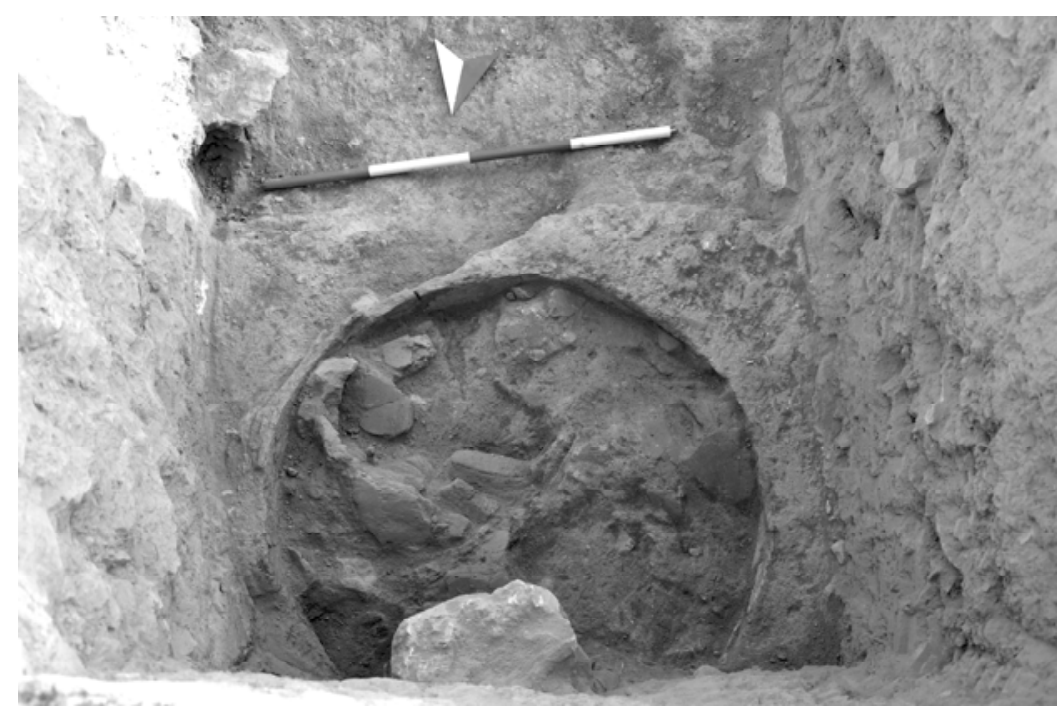

Fig. 7 - Estakhr - Phase 4 - The tannur located at a door of the mosque (photo L. Ebanista). 

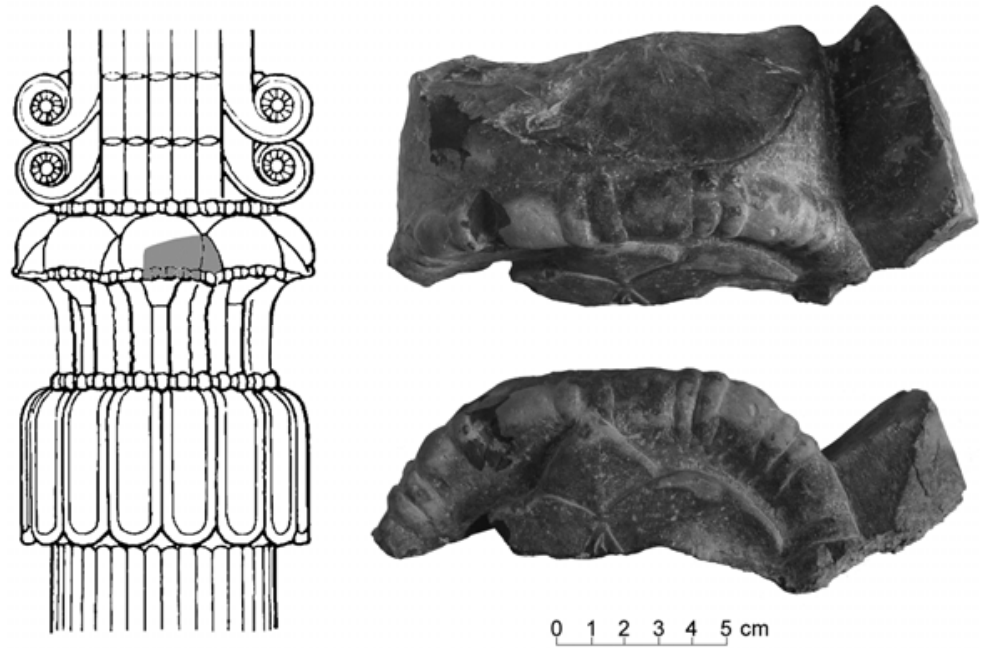

Fig. 8 - Estakhr - Phase 5 - Fragment of an Achaemenid capital re-employed in the mosque wall (photo and rendering A.M. Jaia).

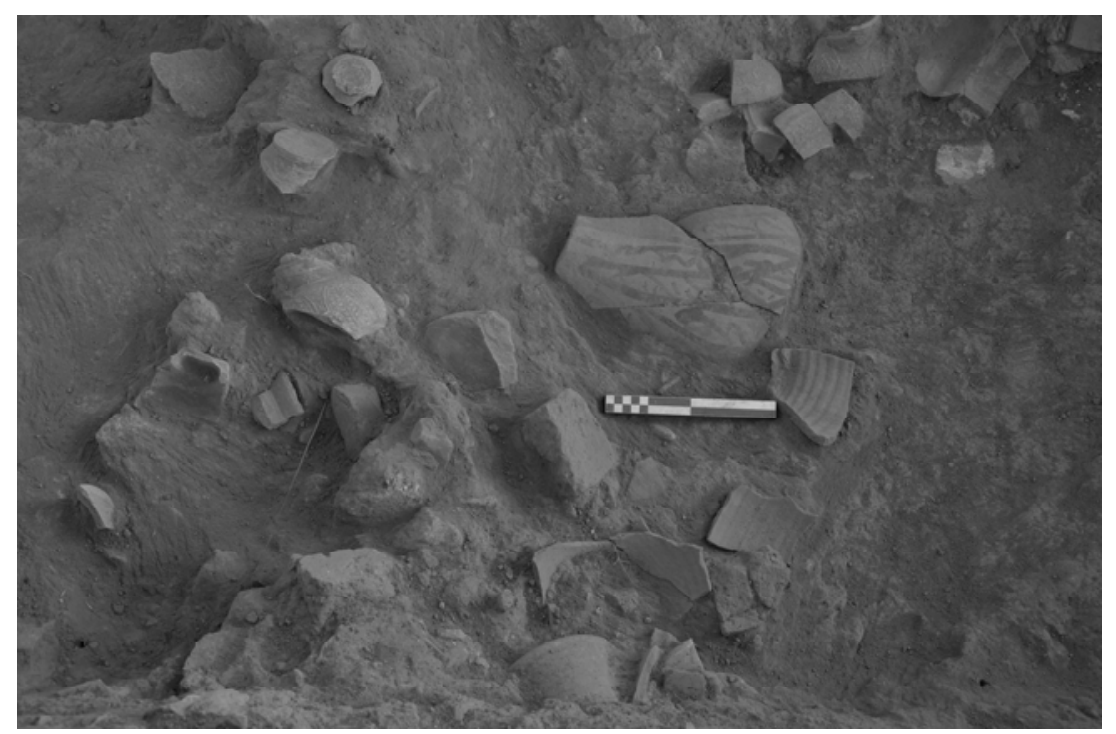

Fig. 9 - Estakhr - Phase 7 - The dump of unglazed pottery $\left(10^{\text {th }}-14^{\text {th }}\right.$ century; photo L. Ebanista). 

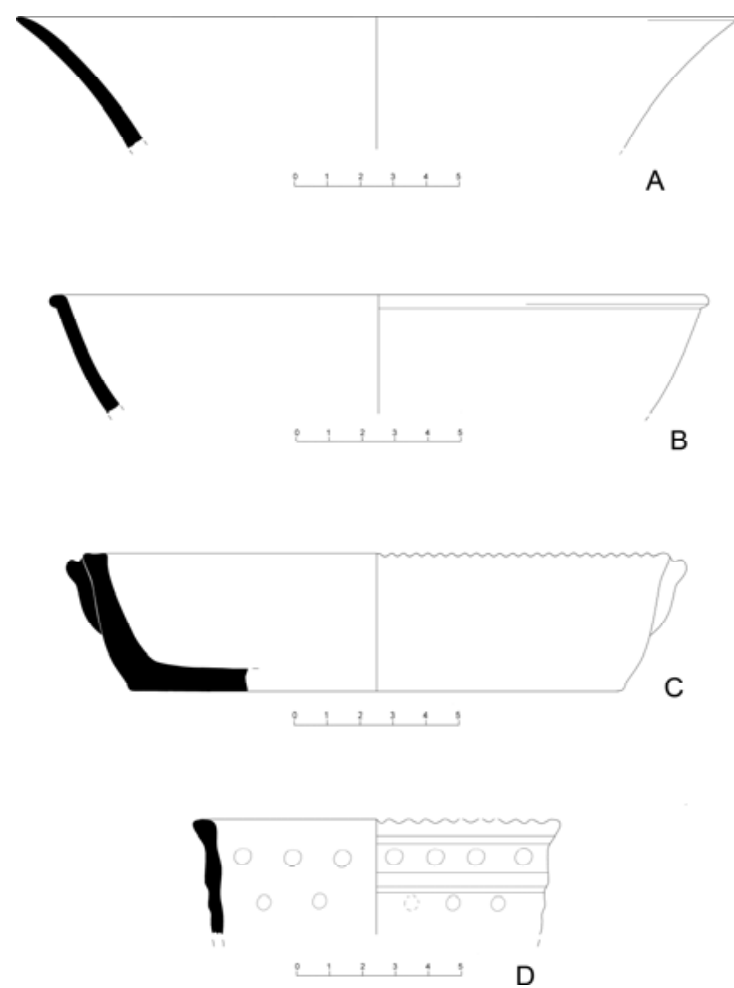

Fig. 10 - Estakhr - A, Inv. ES 46 (SU146) Manganese and turquoise-splashed earthenware; B, Inv. ES 47 (SU 146) Monochrome green-glazed earthenware; C, Inv. ES 62 (SU 159) Opaque turquoise-glazed earthenware with applied decoration; D, Inv. ES 32 (SU 119) Opaque turquoise-glazed earthenware. All drawings are 1:3 in scale (drawings M. Tahmasbi). 


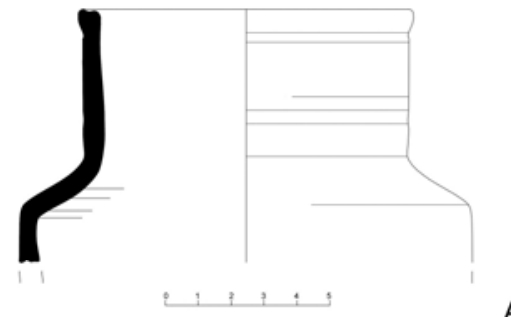

A
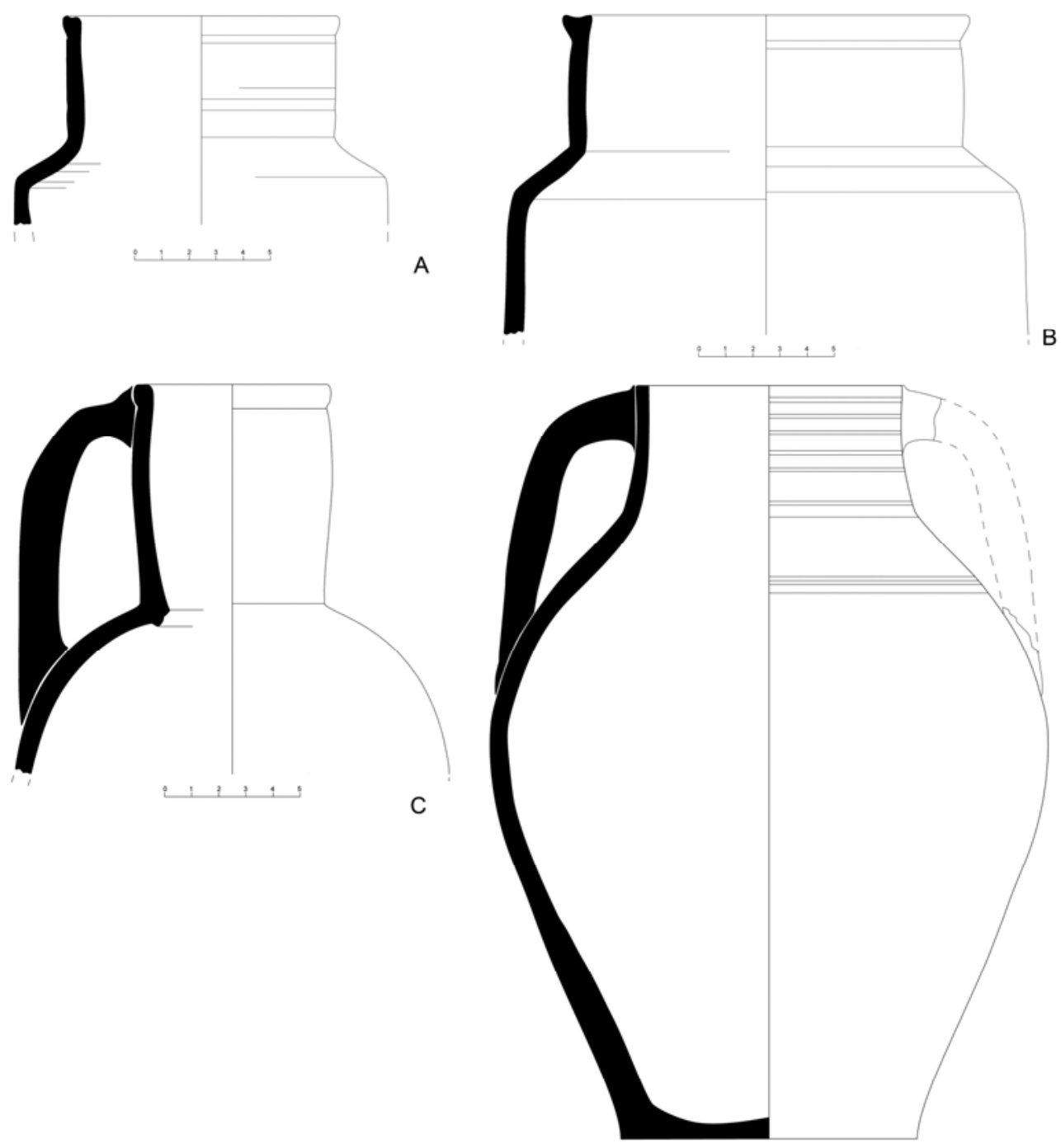

D

Fig. 11 - Estakhr - A, ES 56 (SU 142) Black-slipped earthenware jar; B, Inv. ES 57 (SU 142) Black slipped earthenware jar; C, Inv. ES 53 (SU 142) Molded earthenware jug; D, Inv. ES 52 (SU 142) Painted earthenware jar. All drawings are 1:3 in scale, except D which is 1:4 (drawings $\mathrm{M}$. Tahmasbi). 


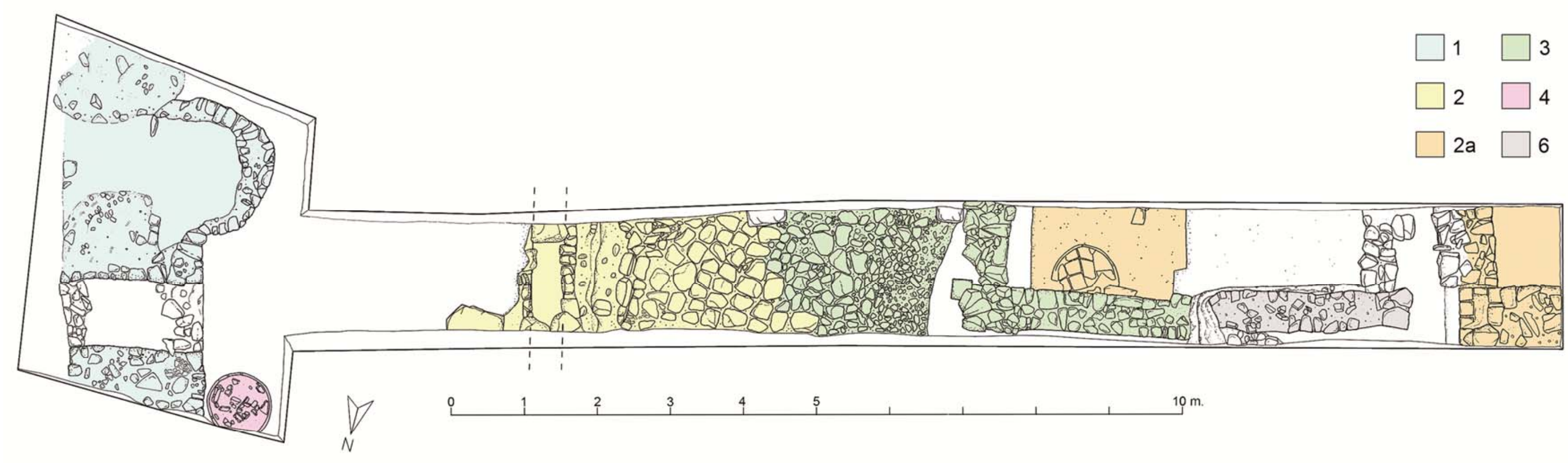

A

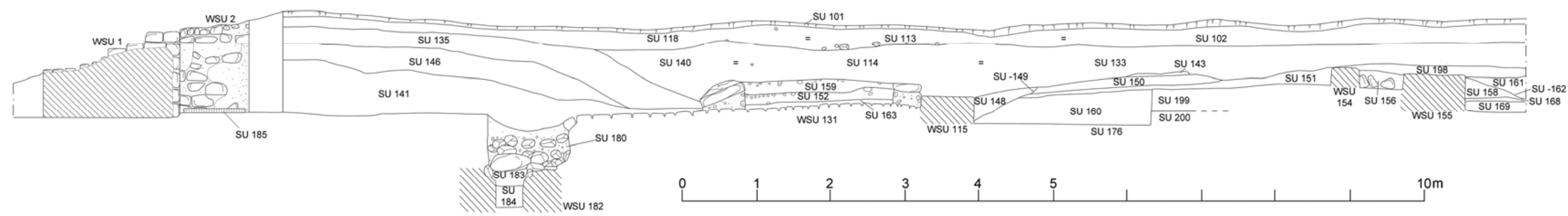

Pl. I - A: Estakhr - General map of the trench: phase 1 - light blue; phase 2 - light ochre; phase 2a - ochre; phase 3 - green; phase 4 - pink; phase 6 - grey (rendering A.M. Jaia) B: Estakhr - East-West section of the excavated trench, south side (rendering A.M. Jaia and L. Ebanista). 